\title{
Influence of Thermal Processing for 3D Printed Components
}

\author{
DRAGOS ALEXANDRESCU1, IULIAN ANTONIAC ${ }^{1}$, CRISTIAN OLTEANU2*, \\ LUCRETIA ANGHEL ${ }^{3}$, NICOLAE SARBU ${ }^{3}$, ROBERT CIOCOIU ${ }^{1 *}$, \\ MIHAELA MONICA SCUTARIU ${ }^{4}$, ZINOVIA SURLARI ${ }^{5}$, NICOLETA IOANID ${ }^{4}$, \\ VICTORITA STEFANESCU ${ }^{3}$
}

${ }^{1}$ University Politehnica of Bucharest, Materials Science and Engineering Faculty, Metallic Materials Science and Physical Metallurgy Department, 313 Splaiul Independentei, 060042, Bucharest, Romania

${ }^{2}$ University of Medicine and Pharmacy "Iuliu Hatieganu", Faculty of Dental Medicine, Orthodontic Discipline, 8 Victor Babes Str., 400000, Cluj Napoca, Romania

${ }^{3}$ Dunarea de Jos University of Galati, Faculty of Medicine and Pharmacy, 47 Domneasca Str., 800008, Galati, Romania ${ }^{4}$ Grigore T. Popa University of Medicine and Pharmacy Iasi, Dental Medical Faculty, 16 Universitatii Str., 700946, Iasi, Romania

${ }^{5}$ Grigore T. Popa University of Medicine and Pharmacy, Faculty of Medical Dentistry, Department of Prosthetic Dentistry, 16 Universitatii Str., 700946, Iasi,Romania

Abstract: In the medical field the additive manufacturing process by fused deposition modeling has gained a great importance given the ability to create complex, organic geometries, in a short time period and the possibility of high customization. By fused deposition process the part is created layer by layer and the resulting part is characterized by high anisotropy, dictated mostly by printing parameters. To alleviate the anisotropy and to study the mechanical behavior of the $3 D$ printed parts thermal processing is used. The materials used as filament is a poly (lactic acid) with copper particles embedded for antibacterial purposes. Samples were $3 D$ printed using a commercial printer, thermally processed and tested in compression. On the failed specimens fracture investigations were performed to understand mechanical behavior during compression. The mechanical characteristics showed improvement and the anisotropy decreased as the processing temperature increased, but the samples became brittle. The mechanical behavior changed drastically on the thermally processed samples because of structural changes: a discontinuity between exterior layers and infill layers was created post layer fusion, the first region being the one stressed and failed first during tests.

Keywords: $3 D$ printing, thermal processing, mechanical properties

\section{Introduction}

Additive manufacturing is a process in which parts are created by the addition of successive layers of materials thus making possible the manufacture of structures with complex geometries, high customization of products and simultaneously reducing material waste [1-3].

This process is currently included in fields such as automotive, aerospace and especially medical and bio-engineering given that most parts are of complex geometry and require a high degree of customization $[3,4]$.

The most used additive manufacturing process is the fused deposition modeling where a filament (made of a thermoplastic polymer, metal or alloy) is extruded from a heated nozzle and deposited, on a predetermined path, layer by layer, to create the required part.

In medical field of wide use is the poly (lactic acid) (PLA), a thermoplastic polymer with characteristics similar to those of petroleum based ones [5], that can be used for various applications with the advantage that it is also biodegradable. Given the increasing concern on health and hygiene PLA has become a matrix for most antibacterial polymer composites [6-18].

A study on literature shows that silver particles are preferred for the production of antibacterial composites [6,9] but lately copper is being used more and more [19 - 22]. 
The advantages of copper over silver include a broad spectrum efficacy against bacteria, viruses and fungi, while silver is less effective against the last two [23], copper is an essential micro-nutrient and enhances wound healing [24], its more durable than silver given its lower solubility while humid and hot environments do not reduce its efficacy $[25,26]$ as it happens with silver.

The mechanical properties of the 3D printed parts depend on a large number of build parameters: layer thickness, degree of infill and its design/orientation, operation temperatures and mechanical properties of the materials used as filaments, thus the resulting part can be thought as made of ancomposite [27-30]. While melting the filament an alignment of polymer molecules is possible [31] andgiven the volumetric shrinkage of printed fibers a weak inter-layer bond is most likely to take place [32].

A series of studies can be found in literature showing that thermal processing of printed 3D parts hasan influence on their mechanical characteristics in that tensile strength, elastic modulus and fracture toughness increase post processing [33 - 36].

The association of 3D printing parameters and thermal processing results in a wide range of possiblemechanical characteristics and behaviors for the same material when used as filament [37]. Along theseaspects the presence of particles used for antibacterial or reinforcing purposes [38-40] might alter material flow in the nozzle and thermal distribution in the part while thermal processing [41].

The aim of our study is to see if the thermal processing of 3D printed parts could improve the physical condition, respectively mechanical properties of 3D printed parts. Enhancing the mechanical characteristics of fused deposition modeled parts could expand their use towards load bearing applications.

\section{Materials and methods}

The samples were made using a commercially available filament (Copper 3D PLACTIVE AN1) made of poly-lactic acid (PLA) with 1\% copper nanoparticles embedded in it for antibacterial purpose.

Cubic samples (10x10x10mm) were designed in a CAD software and printed using a BCN3D SIGMA 3D printer. The nozzle diameter of the extruder head was $0.40 \mathrm{~mm}$ and an extrusion multiplier of 1.00 was used, with printing temperatures of $220^{\circ} \mathrm{C}$ for the nozzle and $80^{\circ} \mathrm{C}$ for the heated bed.

The structure of the printed samples is shown in Figure 1.

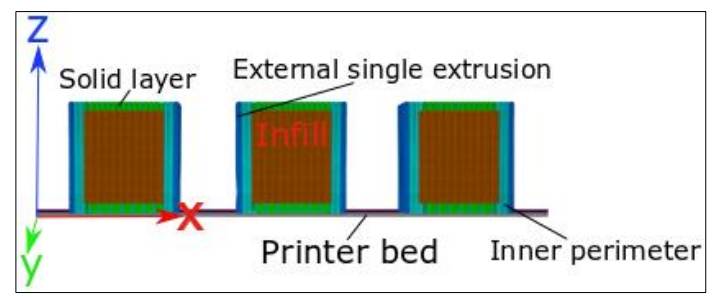

Figure 1. Section view showing the set-up structure of the printed sample

The top and bottom solid layers were in number of eight (as depicted in Figure 2a, b, g and h) with 3 outline perimeter shells ( 1 layer for the single extrusion and 2 layers for the inner perimeter,shown in Figure 2a-h).

The infill was set to $100 \%$ with a rectilinear and alternating pattern $\left(+45^{\circ}-45^{\circ}\right)$ shown in Figure $2 \mathrm{c}-$ f.

Following the above configuration the 3D printed sample was considered to be isotropic in the $\mathrm{x}$ and $\mathrm{y}$ directions while the properties on $\mathrm{z}$ direction are expected to be different.

Since anisotropy is a major concern for 3D printed specimens to alleviate this aspect thermal processing is proposed considering a behavior similar to that of metals during stress annealing: by heating the 3D printed samples internal stresses that occurred during uneven cooling would be reduced and material characteristics improved. 

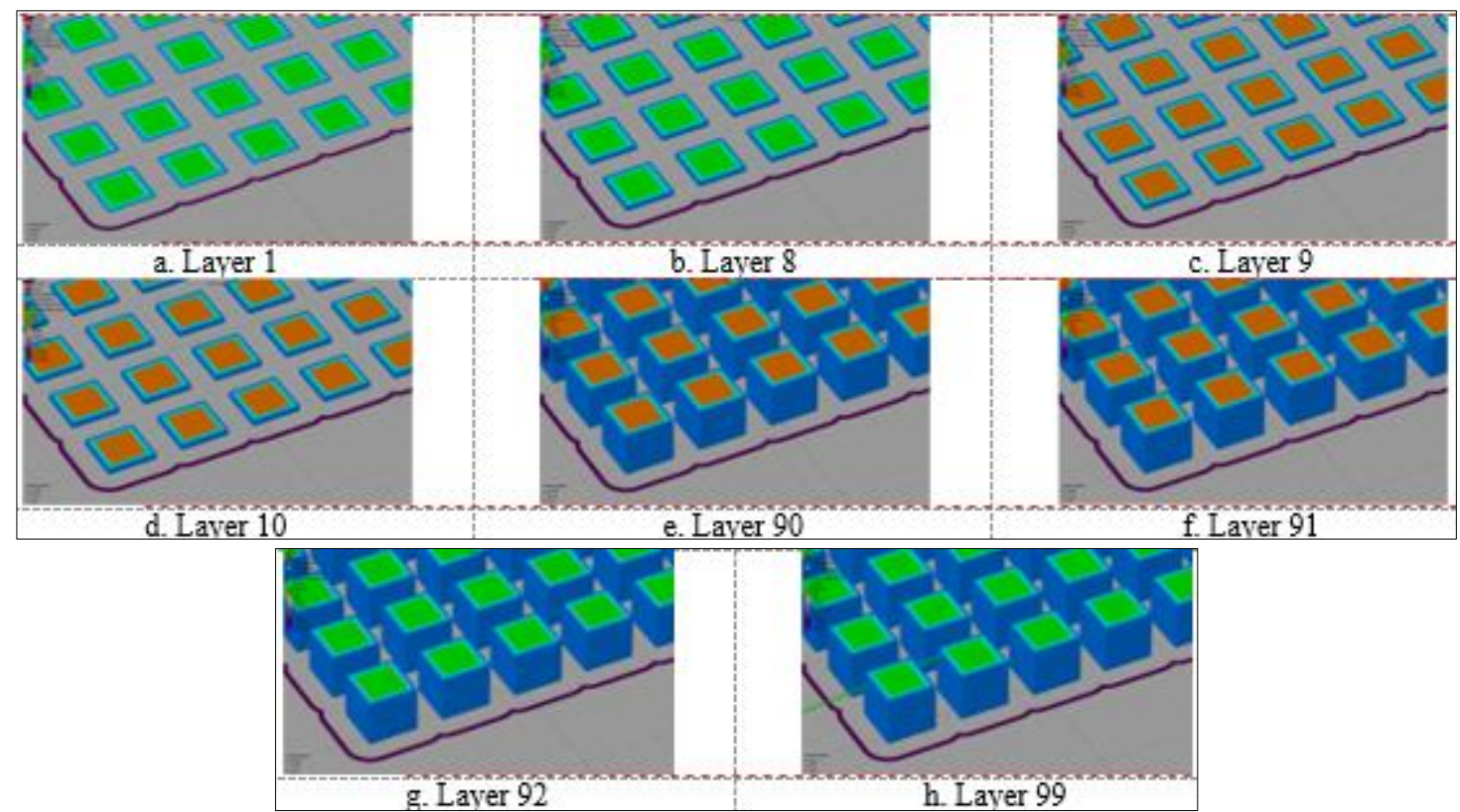

Figure 2. Screen captures depicting layers during 3D printing set-up

The thermal processing was performed in an electrical furnace with samples inserted in a metallic box filled with sodium chloride powder for an uniform heating, Figure 3 shows the process setup.

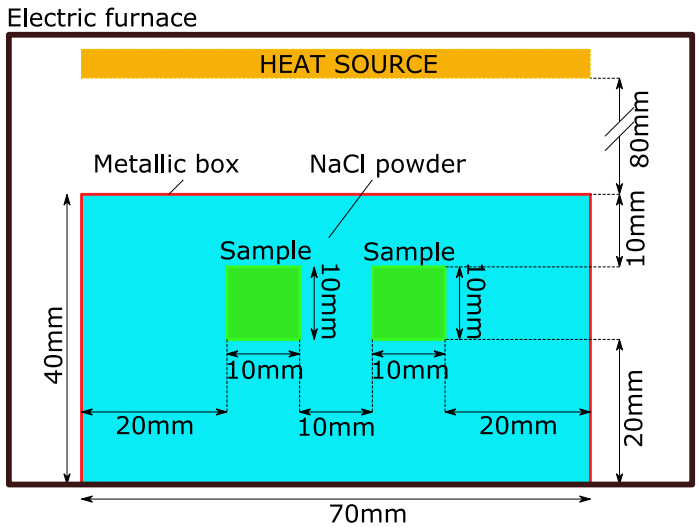

Figure 3. The set-up for thermal Processing of 3D printed samples

The $0.5 \mathrm{~mm}$ thick metallic box was placed directly on the bed of the furnace, and the samples were immersed in the sodium chloride powder according to the schematic above. The orientation of the sample was the same with the one from the printing bed.

The parameters of the thermal processing used are $3 \mathrm{~h}$ holding time at $120,140,160$ and $180^{\circ} \mathrm{C}$. The metallic box was inserted in the furnace when it was already at the holding temperature and cooling was performed in air, by removing the box from the furnace.

For each thermal processing route 6 samples were used, the sample are identified as $\mathrm{R}$ - the reference samples, 3D printed, the thermal processing was performed by holding the samples for $3 \mathrm{~h}$ at $120^{\circ} \mathrm{C}$, samples $\mathrm{T} 1,140^{\circ} \mathrm{C}$ samples $\mathrm{T} 2,160^{\circ} \mathrm{C}$ samples $\mathrm{T} 3$ and $180^{\circ} \mathrm{C}$ for the $\mathrm{T} 4$ samples.

Post thermal processing of the 3D printed samples each set was devised in two groups of 3 samples in respect to printing build-up, parallel $(\|)$ and perpendicular (_l_) to this direction.

The samples were tested in compression using a servo hydraulic universal testing machine using a cross-head speed of $5 \mathrm{~mm} / \mathrm{min}$ and the failed specimen were studied using a stereo-microscope. 


\section{Results and discussions}

The compression test data was processed and following parameters were determined: elastic modulus, elastic limit and the yield strength. Curve correction was performed to compensate the nose and the elastic modulus was determined by performing a linear regression on the straight line of the stress - strain curve. The elastic limit was determined as the point where the stress - strain curve deviates from the linear behavior and the yield strength was determined in a similar manner to that of the conventional yield strength in tension tests, by offsetting by $0.2 \%$.

A selection of stress - strain curves on is presented in Figure 4 showing, by comparison, the mechanical behavior of the tested samples in compression.

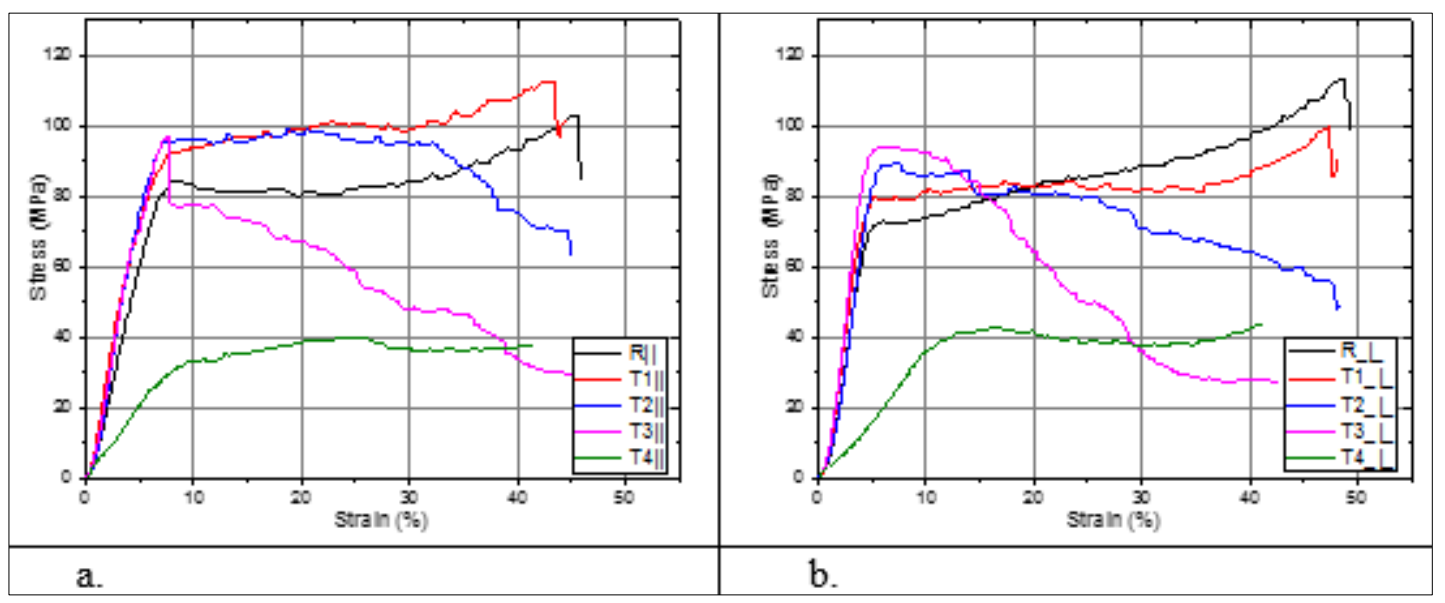

Figure 4. Stress - strain curves showing the mechanical behavior in compression for tested samples in respect to build orientation, a. - parallel and b. - perpendicular to printing direction

The reference samples are malleable as they deform by barreling. The processed samples become less malleable as the treatment temperature increases up to $160^{\circ} \mathrm{C}$. Above this temperature, in the current processing setup, the sample integrity is affected as seen in the aspect of the stress strain curves.

A comparison of average values for elastic modulus, elastic limit and yield strength is depicted in Figure 5.

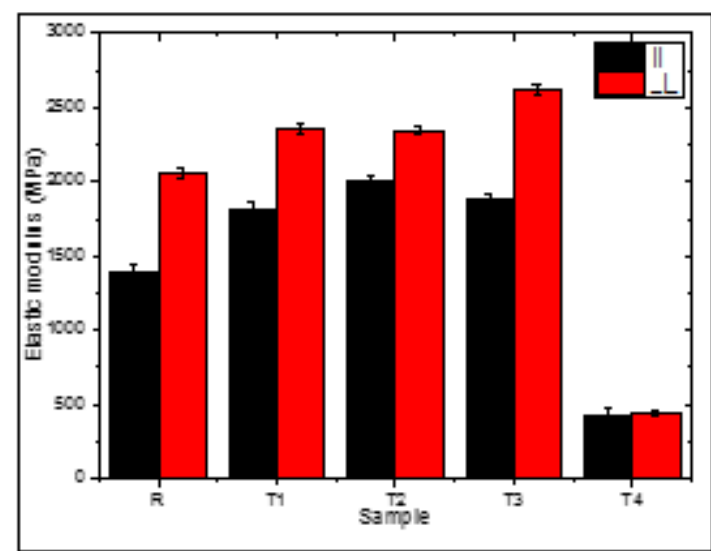

a

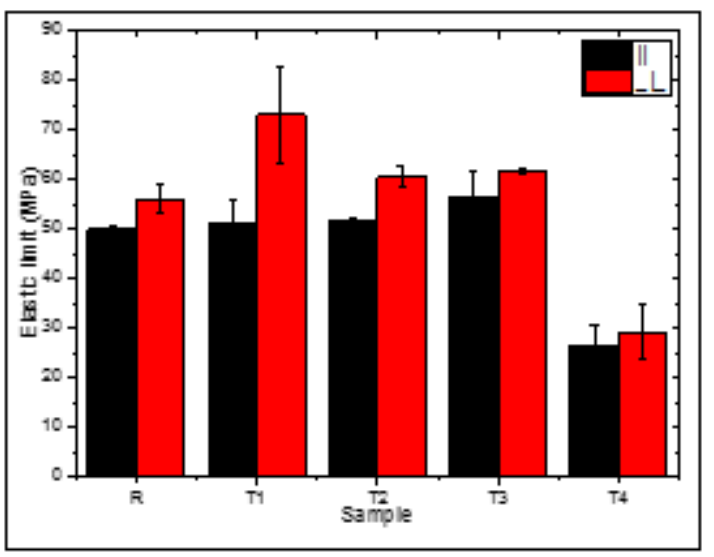

b 

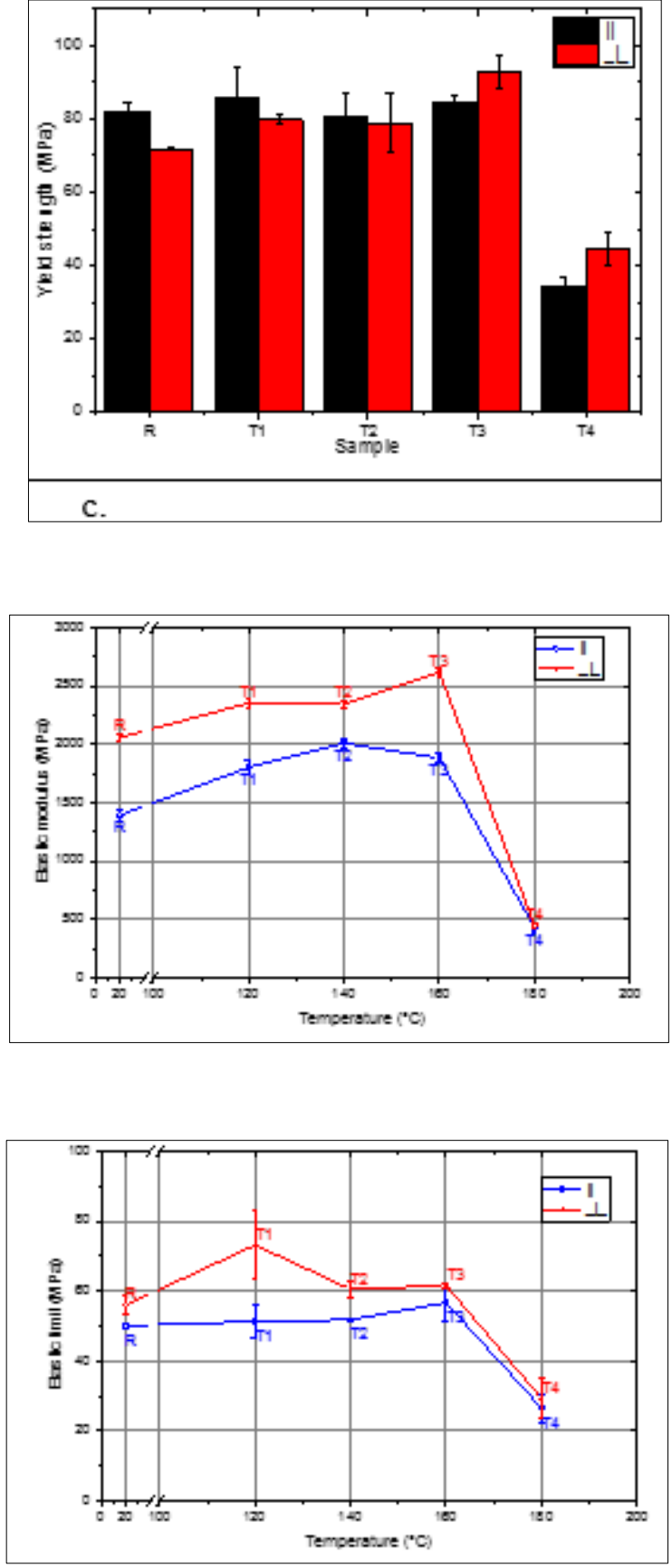

Figure 5. Comparison of average values for the a. elastic modulus, b. elastic limit and c. yield strength of samples on parallel and perpendicular direction
Figure 6. Elastic modulus variation in respect to thermal processing temperature
Figure 7. Elastic limit variation in respect to thermal processing temperature

Processing the samples by thermal treatment clearly induces changes within sample structure, thus the different behavior and mechanical properties.

Including the processing temperature influence on the mechanical characteristics of the samples, in Figure 6-8 the variation for the elastic modulus, elastic limit and yield strength is shown.

The variation of the elastic modulus in respect to thermal processing temperature shown in Figure 5 reveals that by processing the samples at $120^{\circ} \mathrm{C}$ the value of the elastic modulus increases $29.39 \%$ in parallel and by $14.28 \%$ in perpendicular direction. Further increase in processing temperature, at $140^{\circ} \mathrm{C}$, leads to further improvement of the elastic modulus in the parallel direction, by $44.26 \%$, in perpendicular direction its value increased by $13.86 \%$. At $160^{\circ} \mathrm{C}$ the value for the elastic modulus in parallel direction drops by $35.03 \%$, while on perpendicular direction an increase by $27.16 \%$ was computed.

The highest temperature chosen for thermal processing, $180^{\circ} \mathrm{C}$, shows a powerful drop in the value of the elastic modulus, by $69.33 \%$ in parallel and $78.52 \%$ in perpendicular direction. 
The variation of the determined elastic limit in respect to processing temperature is shown in Figure 6 , where for the parallel direction no significant variation is to be observed until heating at $160^{\circ} \mathrm{C}$ is performed. The variations computed are increases by $2.62 \%$ when processing at $120^{\circ} \mathrm{C}, 3.56 \%$ at $140^{\circ} \mathrm{C}$ and $13.39^{\circ} \mathrm{C}$ when processing at $160^{\circ} \mathrm{C}$. The highest temperature used, $180^{\circ} \mathrm{C}$, leads to o severe drop of its value, by $47.02 \%$.

On perpendicular direction a sudden increase by $30.55 \%$ occurred when processing was performed at $120^{\circ} \mathrm{C}, 8.05 \%$ at $140^{\circ} \mathrm{C}$ and $9.94 \%$ at $160^{\circ} \mathrm{C}$. A drop by $47.78 \%$ in the value of the elastic limit when thermal processing was $180^{\circ} \mathrm{C}$ is observed.

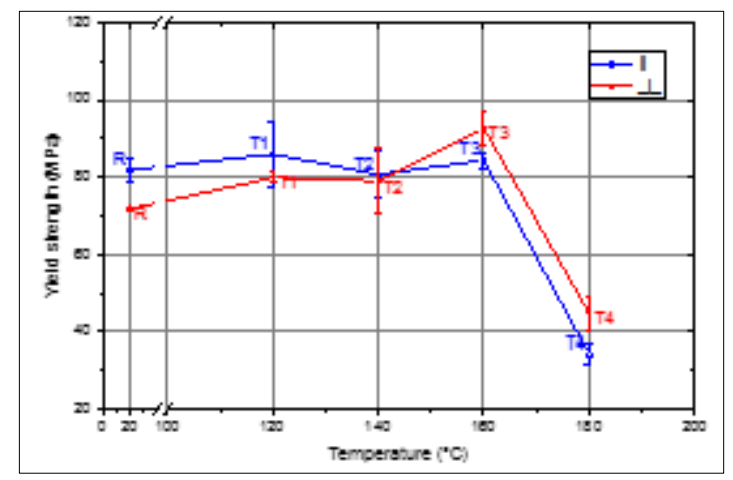

Figure 8. Yield strength variation in respect to thermal processing temperature

The value of the yield strength varies also with the processing temperature, as shown in Figure 7.

On parallel direction little variation is to be observed until $180^{\circ} \mathrm{C}$ : at $120^{\circ} \mathrm{C}$ an increase by $4.97 \%$ was estimated, followed by a slight by $1.44 \%$ at $140^{\circ} \mathrm{C}$ and a slight increase by $3.01 \%$ at $160^{\circ} \mathrm{C}$. At $180^{\circ} \mathrm{C}$ a severe decrease, by $58.16 \%$ was computed.

In perpendicular direction a moderate increase was observed at $120^{\circ} \mathrm{C}$, by $11.16 \%$ and $9.96 \%$ at $140^{\circ} \mathrm{C}$. At $160^{\circ} \mathrm{C}$ the increase is significant, by $29.06 \%$ the yield strength of the samples processed at this temperature supersedes the one for the samples tested on parallel direction. Again, the samples treated at $180^{\circ} \mathrm{C}$ show a decrease in the value of the yield strength by $37.75 \%$.

A ratio defined by dividing the mechanical characteristic value determined on parallel to the one in perpendicular direction is computed. The value of the ratio can be used as a descriptor for the material anisotropy.

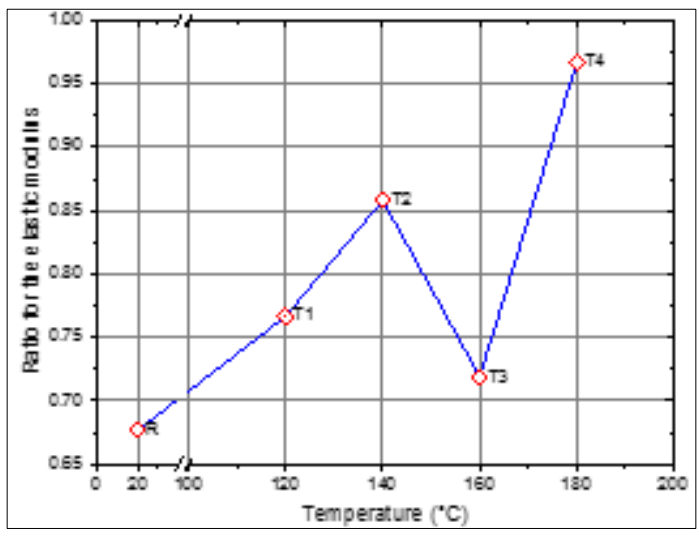

Figure 9. Ratio variation for the elastic modulus in respect to temperature

For the elastic modulus its values shows an increase as temperature increases, an anomaly is observed for the samples treated at $160^{\circ} \mathrm{C}$ (Figure 9), where a drop occurs. 
In Figure 10 the ratio variation for the elastic limit in respect to temperature is shown. It can be seen that thermal processing leads to an initial drop from the initial values, followed by constant increase with increasing temperature.

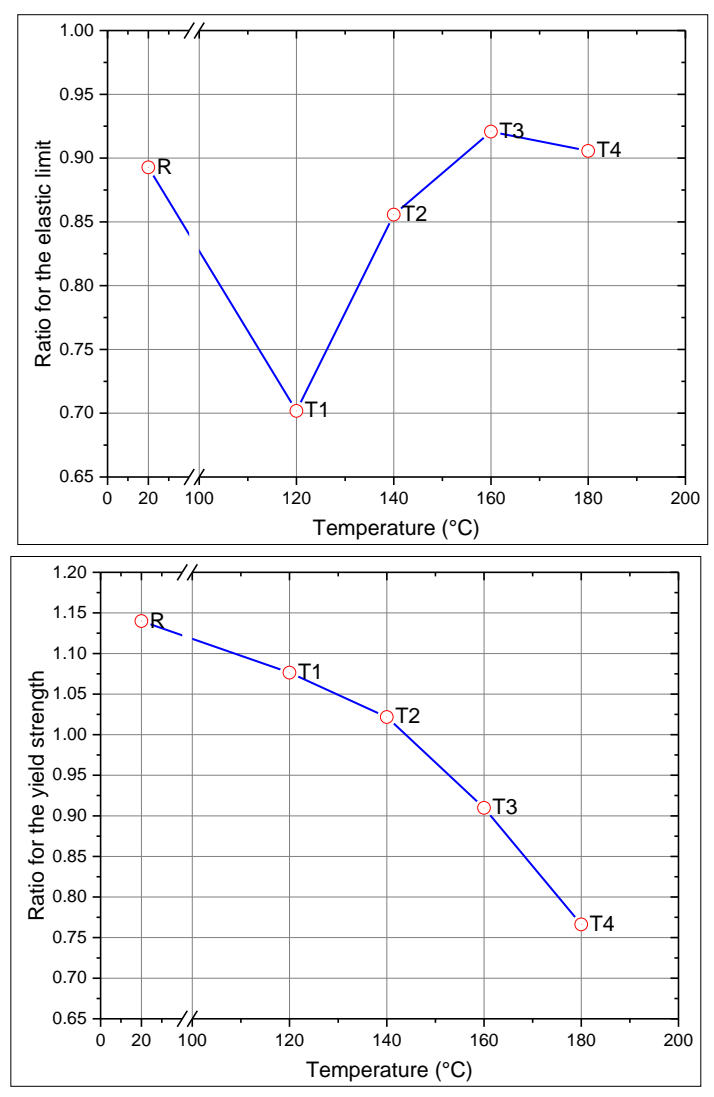

Figure 10. Ratio variation for the elastic limit in respect to temperature

Figure 11. Ratio variation for the yield strength in respect to temperature

The ration for the yield strength seems to drop as the processing temperature increases, as shown in Figure 11. The increase of the value of the yield strength on perpendicular direction is responsible for such variation. A value as close to 1.00 is desirable for an isotropic material which can be obtained by thermal processing at $140^{\circ} \mathrm{C}$ where a ratio value of 1.02 was obtained.

The variation of the results presented above can be explained by changes that occur in the material during thermal processing, in Figure 12 aspects from the surface of the tested samples obtained using a stereo-microscope are shown.

The reference samples oriented parallel to the build-up direction show a significant barreling, as shown in Figure 12a, with little damage to be observed on any of the facets. When thermally processed the damage begins to increase as the processing temperature increases, as depicted by Figure $12 \mathrm{~d}, \mathrm{~g}, \mathrm{j}$ and $\mathrm{m}$.

When oriented on perpendicular direction in respect to build-up direction, the reference samples reveal a fracture type that resembles the fiber fracture of a composite material. As shown in Figure 12b the extruded filaments that constitute the layers begin to fail in the region of tension, since the local stress is a bending one. As the processing temperature increases, at $120^{\circ} \mathrm{C}$ (Figure $12 \mathrm{e}$ ) and $140^{\circ} \mathrm{C}$ (Figure 12h) similar failure mode was observed. At $160^{\circ} \mathrm{C}$ (Figure $12 \mathrm{k}$ ) and at $180^{\circ} \mathrm{C}$ (Figure $12 \mathrm{n}$ ) individual filaments are no longer to be observed since they fused and created a compact material, the highest temperature produces a material that resembles one obtained by plastic injection.

On the other facets of the samples tested perpendicularly it can be seen that cracks developed between individual layers (Figure 12c and f) and at higher temperatures the external single extrusion layer and the inner perimeter layers delaminated completely and exposed the infill layers. The infill layers for the samples processed at $160^{\circ} \mathrm{C}$ show signs of fusion while those processed at $180^{\circ} \mathrm{C}$ reveal a complete fusion. 


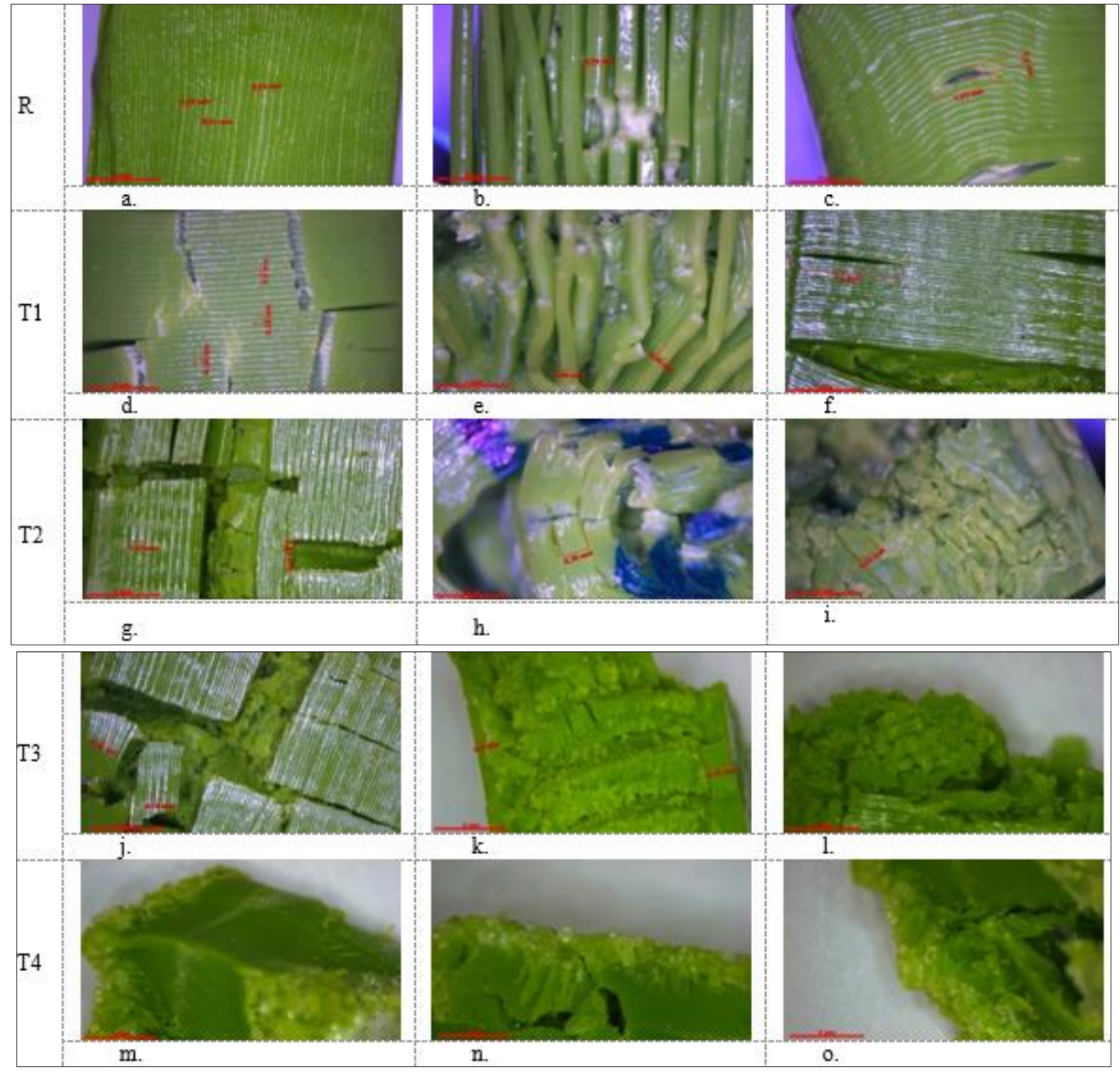

Figure 12. Fracture aspect of tested samples (scale bar is $2 \mathrm{~mm}$ )

The thermal process clearly induces structural changes in the 3D printed samples, yet the mechanical behavior is mostly attributed to the behavior of the most exterior layers: the solid, external single extrusion and inner perimeter layers.

The fracture aspects shown in Figure 12 show that, at higher temperatures, exterior and infill layers begin to fuse and the cohesion between these regions is quite poor. The external layers take all the stresses during the test and fail.

At $180^{\circ} \mathrm{C}$ the PLA reaches it's melting temperature and in the exterior layers grains of $\mathrm{NaCl}$ are embedded, thus the poor mechanical behavior of the T4 samples.

\section{Conclusions}

In this study it was aimed to see how thermal processing of 3D printed parts made of antibacterial PLA composites would alter the mechanical behavior and properties. It was shown that the strength characteristics (elastic modulus, elastic limit and yield strength) increase as thermal processing temperature increases, but a decline in plasticity occurs. The anisotropy of the parts is reduced also with increasing temperatures. The current setup for thermal processing of PLA parts can be used successfully 
up to and including temperatures of $160^{\circ} \mathrm{C}$, above this temperature a new design is required since melting of the exterior layers of the part can embed particles.

The structure of the printed part changes with increasing processing temperature, starting from $160^{\circ} \mathrm{C}$ layer fusion becomes significant, aspect that changes the mechanical behavior drastically: the loads are distributed on the exterior layers which fail first.

The copper particles embedded in the PLA filament did not show any influence on the mechanical behavior of printed and thermally processed parts.

Using a temperature of $160^{\circ} \mathrm{C}$ in the current processing set-up ensures best mechanical characteristics and reduced anisotropy, yet taking into account the second influence factor, holding time, further optimization is possible.

The set of characteristics obtained post thermal processing at $160^{\circ} \mathrm{C}$ come in the close range of polyiminocarbonates.

\section{References}

1.ZHANG, X.Z., CHEN, L., MULHOLLAND, T., OSSWALD, T.A., Characterization of mechanical properties and fracture mode of PLA and copper/PLA composite part manufactured by fused deposition modeling, SN Applied Science, 1, 2019, Article Number: 616.

https://doi.org/10.1007/s42452-019-0639-5.

2.KALSOOM, U., NESTERENKO, P.N., PAULL, B., Recent developments in 3D printable composite materials, Rsc. Adv., 6, 2016, 60355-60371.

3.CAMPBELL, I., BOURELL, D., GIBSON, I., Additive manufacturing: rapid prototyping comes of age, Rapid Prototyping J., 18, 2012, 255-258.

4. JAMROZ, W., SZAFRANIEC, J., KUREK, M., JACHOWICZ, R., 3D Printing in Pharmaceutical and Medical Applications - Recent Achievements and Challenges, Pharm. Research, 35(9), 2018, Article Number: 176. DOI: 10.1007/s11095-018-2454-x.

5. EARAR, K., GURAU, G., STEFANESCU, V., CARP, G.B., PAVEL, L.L., BOSINCEANU, D., HURJUI, L.L., MURARIU, A., BERBECE, S., IORDACHE, C., BALOS, M., FULGA, I., FRATILA, D.N., BEZNEA, A., Improvement of Acrylic Resins Structure in Removable Prosthesis Base Polymerization, Mater. Plast., 57(4), 2020, 353-359.

6.WANG, H.B., ZHAO, X.Y., XI, W., WEI, Q.F., GAO, W.D., Antibacterial properties of PLA nonwoven medical dressings deposited with nanostructured silver films, International Forum on Biomedical Textile Materials, Proceedings, 2007, 247-252.

7. FEI, Y.N., CHEN, Y., WANG, H.B., GAO, W.D., YANG, R.H., WAN, Y.Q., Preparation, Characterization of Antibacterial PLA/TP Nanofibers, Fiber Polym., 12, 2011, 340-344.

8.KAYACI, F., UMU, O.C.O., TEKINAY, T., UYAR, T., Antibacterial Electrospun Poly(lactic acid) (PLA) Nanofibrous Webs Incorporating Triclosan/Cyclodextrin Inclusion Complexes, J. Agr. Food Chem., 61, 2013, 3901-3908.

9.MUNTEANU, B.S., AYTAC, Z., PRICOPE, G.M., UYAR, T., VASILE, C., Polylactic acid (PLA)/ Silver-NP/VitaminE bionanocomposite electrospun nanofibers with antibacterial and antioxidant activity, J. Nanopart. Res., 16(10), 2014, Article Number 2643. DOI: 10.1007/s11051-014-2643-4.

10.TOFOLEANU, F., MINDRU, T.B., BRINZA, F., SULITANU, N., SANDU, I.G., RRAILEANU, D., FLORISTEAN, V., HAGIU, B.A., IONESCU, C.,SANDU, I., TURA, V., Electrospun gelatin nanofibers functionalized with silver nanoparticles, Journal of Optoelectronics and Advanced Materials, 10(12), 2008, 3512-3516.

11.TURA, V., TOFOLEANU, F., MANGALAGM, I., MINDRU, T.B., BRINZA, F., SULITANU, N., SANDU, I., RAILEANU, I.D., IONESCU, C., Electrospinning of gelatin/chitin composite nanofibers, Journal of Optoelectronics and Advanced Materials, 10(12), 2008, 3505-3511.

12.DAVOODI, S., OLIAEI, E., DAVACHI, S.M., HEJAZI, I., SEYFI, J., HEIDARI, B.S., 
EBRAHIMI, H., Preparation and characterization of interface-modified PLA/starch/PCL ternary blends using PLLA/triclosan antibacterial nanoparticles for medical applications, Rsc. Adv., 6(46), 2016, 39870-39882. DOI:10.1039/c6ra07667j.

13.MERINO, D., MANSILlA, Y., CASALONGUE, C., ALVAREZ, V., Physicochemical and Antibacterial Properties of Pla-Chitosan Blends Obtained by Casting with Potential Use as Agricultural Mulch Films, Av. Cienc. Ing., 7, 2016, 27-39.

14.KAZMIERCZAK, D., GUZINSKA, K., DYMEL, M., Antibacterial Activity of PLA Fibres Estimated by Quantitative Methods, Fibres Text. East. Eur., 24, 2016, 126-130.

15.KOST, B., SVYNTKIVSKA, M., BRZEZINSKI, M., MAKOWSKI, T., PIORKOWSKA, E., RAJKOWSKA, K., KUNICKA-STYCZYNSKA, A., BIELA, T., PLA/beta-CD-based fibres loaded with quercetin as potential antibacterial dressing materials, Colloid Surface B, 190, 2020, Article Number: 110949. DOI: 10.1016/j.colsurfb.2020.110949.

16.VALERINI, D., TAMMARO, L., VIGLIOTTA, G., PICARIELLO, E., BANFI, F., CAVALIERE, E., CIAMBRIELlO, L., GAVIOLI, L., Ag Functionalization of Al-Doped ZnO Nanostructured Coatings on PLA Substrate for Antibacterial Applications, Coatings, 10(12), 2020, Article Number: 1238. DOI: $10.3390 /$ coatings 10121238.

17.HRISTIAN, L., BORDEIANU, D.L., IUREA, P., SANDU, I., EARAR, K., Study of the Tensile Properties of Materials Destined to Manufacture Protective Clothing for Firemen, Mater. Plast., 51(4), 2014, 405-409.

18.MANEA, L.R., SCARLET, R., LEON, A.L., SANDU, I., Control of Nanofibers Production Process Through Electrospinning, Rev. Chim., 66(5), 2015, 640-644.

19.GHUGLOT, R., TITUS, W., AGNIHOTRI, A. S., KRISHNAKUMAR, V., KRISHNAMOORTHY, G., MARIMUTHU, N., Stable copper nanoparticles as potential antibacterial agent against aquaculture pathogens and human fibroblast cell viability, Biocatal. Agr. Biotech., 32, 2021, Article Number: 101932. DOI: 10.1016/j.bcab.2021.101932.

20.SOUSA, B.C., MASSAR, C.J., GLEASON, M.A., COTE, D.L., On the emergence of antibacterial and antiviral copper cold spray coatings, J. Biol. Eng., 15, 2021, Article Number: 8.

DOI: 10.1186/s13036-021-00256-7.

21.CHOI, J., KIM, J., HAN, K., KIM, U., Antibacterial behavior of copper glazes: effect of copper(II) oxide concentrations and sintering atmospheres, J. Korean Ceram. Soc., 58, 2021, 287-296.

22.NGUYEN, N. Y., AN, B. N., LE, M. V., HOANG, H. A., Antibacterial Activity of Copper Nanoparticles-Chitosan Composite against Vibrio parahaemolyticus. Biocontrol Sci., 25, 2020,159-165.

23.MINOSHIMA, M., LU, Y., KIMURA, T., NAKANO, R., ISHIGURO, H., KUBOTA, Y.,

HASHIMOTO, K., SUNADA, K., Comparison of the antiviral effect of solid-state copper and silver compounds, Journal of Hazardous Materials, 312, 2016, 1-7. DOI: 10.1016/j.jhazmat.2016.03.023.

24.***National Research Council (US) Committee on Copper in Drinking Water. Copper in Drinking Water. Washington (DC): National Academies Press (US); 2000. 2, Physiological Role of Copper, https://www.ncbi.nlm.nih.gov/books/NBK225407/(accessed on 15 May 2021).

25.LEHTONEN, J., HASSINEN, J., HONKANEN, R., KUMAR, A.A., VISKARI, H., KETTUNEN, A., PAHIMANOLIS, N., PRADEEP, T., ROJAS, O. J., IKKALA, O., Effects of Chloride Concentration on the Water Disinfection Performance of Silver Containing Nanocellulose-based Composites, Scientific Reports, 9, 2019, Article Number: 19505.

26.MICHELS, H.T., NOYCE, J.O., KEEVIL, C.W., Effects of temperature and humidity on the efficacy of methicillin-resistant Staphylococcus aureus challenged antimicrobial materials containing silver and copper, Letters in Applied Microbiology, 49, 2009, 191-195.

27.BOLCU, D., STANESCU, M.M., CIUCA, I., MIRITOIU, C.M., DINITA, A., BOLCU, A., A Study Regarding the Mechanical Properties of a Hybrid Matrix with Various Volume Proportions of Dammar, Mater. Plast, 57(1), 2020, 133-140.

28.CIUCA, I., STANESCU, M.M., BOLCU, D., A Study on the Mechanical Properties of Some GreenComposites, Environ. Eng. Manag. J., 17, 2018, 2991-2998. 
29.CIUCA, I., BOLCU, A., STANESCU, M.M., A Study on Some Mechanical Properties of BioComposite Materials with a Dammar-Based Matrix, Environ. Eng. Manag. J., 16, 2017, 2851-2856.

30.BOLCU, D., STANESCU, M.M., CIUCA, I., DUMITRU, S., SAVA, M., The Non-uniformity from the Composite Materials Reinforced with Fiber Glass Fabric, Mater. Plast., 51(1), 2014, 97-100.

31.GHODBANE, S.A., MURTHY, N.S., DUNN, M.G., KOHN, J., Achieving molecular orientation in thermally extruded 3D printed objects, Biofabrication, 11(4), 2019, Article Number: 045004. DOI: 10.1088/1758-5090/ab1d44.

32.ES-SAID, O.S., FOYOS, J., NOORANI, R., MENDELSON, M., MARLOTH, R., PREGGER, B. A., Effect of layer orientation on mechanical properties of rapid prototyped samples, Mater. Manuf. Process, 15, 2000, 107-122.

33.CHRISTIYAN, K.G.J., CHANDRASEKHAR, U., VENKATESWARLU, K., A study on the influence of process parameters on the Mechanical Properties of 3D printed ABS composite, 2nd International Manufacturing Engineering Conference (IMEC-2015) and 3rd Asia-Pacific Conference on Manufacturing Systems (APCOMS-2015), 2016, Article Number: 114.

34.YANG, C.C., TIAN, X.Y., LI, D.C., CAO, Y., ZHAO, F., SHI, C. Q., Influence of thermal processing conditions in 3D printing on the crystallinity and mechanical properties of PEEK material, J. Mater. Process Tech., 248, 2017, 1-7.

35.GENG, P., ZHAO, J., WU, W.Z., WANG, Y.L., WANG, B.F., WANG, S.B., LI, G.W., Effect of Thermal Processing and Heat Treatment Condition on 3D Printing PPS Properties, Polymers, 10(8), 2018, Article Number: 875. DOI: 10.3390/polym10080875.

36.WANG, R., CHENG, K.J., ADVINCULA, R.C., CHEN, Q.Y., On the thermal processing and mechanical properties of 3D-printed polyether ether ketone, MRS Communications, 9(3), 2019, 10461052.

37.ZALDIVAR, R.J., WITKIN, D.B., MCLOUTH, T., PATEL, D.N., SCHMITT, K., NOKES, J.P., Influence of processing and orientation print effects on the mechanical and thermal behavior of 3DPrinted ULTEM (R) 9085 Material., Addit. Manuf., 13, 2017, 71-80.

38.POPA, D., CONSTANTINIUC, M., EARAR, K., MERCUT, V., SCRIECIU, M., BUDURU, S., LUCA, E., NEGUCIOIU, M., Review of Different Materials that can be CAD/CAM Processed Description, chemical composition, indications in dentistry areas, Rev. Chim., 70(11), 2019, 4029-4034. 39.EARAR, K., GRIGORE, C.A., ANTOHE, M.E., FOTEA, S., BEZNEA, A., BERBECE, S., BRATU, A.M., DINU, C.A., MARIS, M., GURAU, G., TOPOR, G., ONISOR, C., FEIER, R., Influence of Alumina Nanoparticles on the Mechanical Properties of a Bioresin Composite, Mater. Plast., 58(1), 2021, 248-256.

40.TOPOR, G., EARAR, K., CIUCA, I., BERBECE, S., STEFANESCU, V., BEZNEA, A., GRIGORE, C.A., MARIS, M., FOTEA, S., ONISOR, C., FEIER, R., IORDACHE, C.M., GURAU, G., Mechanical Properties of Bis-GMA/HEMA Resin Composite with Addition of Silicon Dioxide Nanoparticles, Mater. Plast., 58(1), 2021, 257-264.

41.TECU, C., ANTONIAC, A., GOller, G., GOK, M.G., MANOLE, M., MOHAN, A., MOLDOVAN, H.; EARAR, K., The Sintering Behaviour and Mechanical Properties of Hydroxyapatite - Based Composites for Bone Tissue Regeneration, Rev. Chim., 69(5), 2018, 1272-1275.

$\overline{\text { Manuscript received: } 30.07 .2021}$ 